\title{
PENGARUH PERINTAH PERJALANAN DINAS TERHADAP PENINGKATAN MOTIVASI KERJA APARATUR SIPIL NEGARA DI SEKRETARIAT DPRD KABUPATEN BENGKALIS
}

\author{
Muhammad Elsa Tomisa, Nadrah \\ Sekolah Tinggi Ilmu Ekonomi (STIE) Syariah Bengkalis \\ elsatomisa@gmail.com,nadrah.nad@yahoo.com
}

\begin{abstract}
The Secretariat of the Bengkalis Regency Regional Representative Council has used official travel orders as a step to increase work motivation of its employees or employees. In this research, the author wants to examine how official travel procedures are and whether there is an effect of providing official travel with work motivation by reason of wages in addition to their income, as well as an Islamic perspective on official travel. This study uses quantitative descriptive methods. From this study, it was found that the Secretariat of the Bengkalis Regency Regional Representative Office had used procedures in accordance with the Regulations of the Regent No. 82 of 2017. Then there was a significant influence of the Official Travel Order on Work Motivation of the Civil Civil Apparatuses in the Bengkalis Regency Regional Representative Council Secretariat. Meanwhile, according to the perspective of sharia, there is nothing wrong as long as it is run according to the rules.
\end{abstract}

Keywords: Official Travel Commands, Work Motivation, State Civil Apparatus.

\begin{abstract}
ABSTRAK
Sekretariat DPRD Kabupaten Bengkalis telah menggunakan cara perintah perjalanan dinas sebagai salah satu langkah untuk meningkatkan motivasi kerja para karyawan atau pegawainya. Dalam kajian ini penulis ingin mengkaji bagaimana prosedur perjalanan dinas dan apakah ada pengaruh pemberian perjalanan dinas dengan motivasi kerja dengan alasan upah sebagai tambahan pendapatan mereka, serta perspektif islam tentang perjalanan dinas. Kajian ini menggunakan metode deskriftif kuantitatif. Dari kajian ini menemukan bahwa kantor Sekretariat DPRD Kabupaten Bengkalis sudah menggunakan prosedur sesuai dengan Peraturan Bupati No. 82 tahun 2017. Kemudian terdapat pengaruh yang signifikan dari Perintah Perjalanan Dinas terhadap Motivasi Kerja Aparatur Sipil Negara di lingkungan Sekretariat DPRD Kabupaten Bengkalis. Sedangkan menurut perspektif syariah tidak ada yang menyalahi selama dijalankan sesuai dengan aturannya.
\end{abstract}

Kata Kunci: Perintah Perjalanan Dinas, Motivasi Kerja, Aparatur Sipil Negara.

\section{PENDAHULUAN}

Sumber daya manusia merupakan salah satu unsur yang sangat menentukan keberhasilan suatu organisasi mencapai tujuan, orang merupakan 
unsur yang sangat penting dalam organisasi. Didalam sebuah instansi pemerintah, pegawai senantiasa menginginkan penghasilan yang lebih. Sedangkan diketahui sistem penggajian Pegawai Negeri Sipil atau Aparatur Sipil Negara saat ini masih dibawah gaji swasta sehingga berpengaruh terhadap kinerja dan produktivitas kerja. Untuk meningkatkan kinerja dan produktivitas pegawai dibutuhkan motivasi (Mangkunegara 2004).

Motivasi merupakan tindakan untuk mempengaruhi dan mendorong seseorang untuk berperilaku. Secara pasif, motivasi tampak sebagai pendorong yang dapat mengerakkan semua potensi, baik karyawan maupun sumber daya lainnya. Dari segi aktif, motivasi tapak sebagai usaha positif dalam menggerakkan daya dan potensi karyawan agar secara produktif untuk berhasil mencapai tujuan. Seberapapun tingkat kemampuan yang dimiliki seseorang, pasti butuh motivasi. Karena potensi sumber daya manusia adalah suatu yang terbatas. Dengan demikian, kinerja seseorang merupakan fungsi dari faktor-faktor kemampuan dan motivasi dirinya (Siagian 1989, 41).

Winardi $(2002,45)$ menjelaskan bahwa motivasi untuk bekerja merupakan sebuah istilah yang digunakan dalam bidang perilaku keorganisasian (organizational behavior), guna menerangkan kekuatan-kekuatan yang terdapat pada diri seseorang individu, yang menjadi penyebab timbulnya tingkat, arah dan persistensi upaya yang dilaksanakan dalam hal bekerja. Dengan demikian analisis mengenai motivasi akan bersinggungan dengan faktor-faktor yang mempengaruhi motivasi. Ditegaskan bahwa analisis motivasi perlu memusatkan perhatian pada faktor-faktor yang menimbulkan dan mengarahkan aktivitas-aktivitas seseorang.

Undang-Undang Nomor 43 Tahun 1999 tentang Pokok-pokok Kepegawaian pasal 33 ayat 1 dan 2 yaitu: ayat 1 berbunyi "untuk mendorong dan meningkatkan prestasi kerja serta untuk memupuk kesetiaan terhadap Negara maka kepada pegawai negeri sipil yang telah menunjukkan kesetiaan atau telah berjasa terhadap Negara atau yang menunjukkan prestasi kerja yang luar biasa sebaiknya dapat diberikan penghargaan oleh pemerintah". Ayat 2 yang berbunyi: "penghargaan yang dimaksud dapat berupa tanda jasa, kenaikan pangkat istimewa atau bentuk penghargaan lainnya, seperti surat pujian penghargaan yang berupa material dan lain-lain".

Salah satu upaya yang dilakukan instansi dalam memberikan motivasi kepada karyawan yaitu dengan Perintah Perjalan Dinas. Perintah perjalanan dinas selain sebagai tugas perjalanan dinas merupakan salah satu usaha untuk meningkatkan kualitas kerja karyawan dan juga untuk memenuhi kebutuhan karyawan. Karyawan suatu perusahaan ataupun instansi akan bekerja lebih giat dan semangat sesuai dengan harapan pimpinan atau instansi, jika instansi memperhatikan dan memenuhi kebutuhan para pegawainya, baik kebutuhan yang bersifat materi maupun kebutuhan yang bersifat non materi.

Pimpinan instansi hendaknya selalu memotivasi karyawan untuk berprestasi lebih baik. Oleh karena itu, motivasi merupakan hal yang sangat penting untuk diperhatikan dalam rangka meningkatkan kinerja karyawan. Hal ini sesuai dengan firman Allah SWT. Surat Az-Zumar ayat 39 (Kemenag RI 2006, 329):

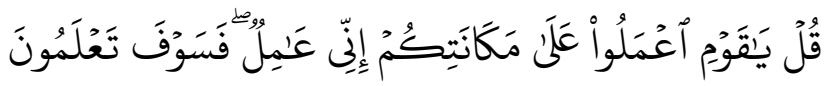


Artinya: "Hai kaumku, bekerjalah sesuai dengan keadaanmu, sesunguhnya Aku akan bekerja (pula), maka kelak kamu akan mengetahui”.

Dari berbagai tugas pemimpin dalam suatu birokrasi, maka tugas yang paling sulit yang harus dilaksanakan adalah bagaimana memotivasi pengikut atau bawahannya agar mereka mau bekerja lebih giat dan penuh tanggung jawab. Dikatakan sulit oleh karena sifat motivasi itu sendiri bersifat abstrak dan tidak dapat berlaku secara universal pada setiap individu dalam suatu birokrasi. Suatu perlakuan tertentu yang berhasil meningkatkan motivasi seseorang pada waktu tertentu belum tentu berhasil apabila diterapkan kepada orang lain pada tempat dan waktu yang berbeda (Pawewang 2015, 5).

Bekerja menurut ajaran Islam merupakan suatu kewajiban secara menyeluruh atas setiap orang yang mampu bekerja untuk mencapai kebahagiaan individu atau masyarakat. Bekerja dan beramal hendaklah sesuai dengan ketentuan syari'at Islam, karena pekerjaan tersebut akan dipertanggungjawabkan dan dilihat oleh manusia dan Allah. Allah Maha mengetahui setiap pekerjaan yang dilakukan oleh manusia merasa nyata ataupun yang ghaib (Sukirwan 2018).

Demikian pula halnya pada Sekretariat DPRD Kabupaten Bengkalis telah menggunakan cara Perintah perjalanan dinas sebagai salah satu langkah untuk meningkatkan motivasi kerja para karyawan atau pegawainya. Sekretariat DPRD Kabupaten Bengkalis dalam kegiatan perkantorannya menggunakan Surat Perintah Perjalanan Dinas (SPPD), yaitu surat pengantar yang dibuat ketika pegawainya akan melakukan perjalanan dinas ke kota tertentu. Namun berdasarkan observasi awal peneliti Perintah perintah perjalanan dinas ini terkadang ada kesenjangan diantara ASN yang ada di DPRD Kabupaten Bengkalis, akibatnya dari kesenjangan ini akan berdampak pada motivasi kinerja ASN itu sendiri. Untuk itu penelitian ini bertujuan untuk mengetahui bagaimana perjalanan dinas di Seketariat DPRD Kabupaten Bengkalis, untuk menganalisis pengaruh perintah perjalanan dinas terhadap peningkatan motivasi kerja aparatur sipil negara di Sekretariat DPRD Kabupaten Bengkalis, untuk mengetahui apakah perintah perjalanan dinas di Sekretariat DPRD Kabupaten Bengkalis sesuai dengan perspektif Islam.

\section{TELAAH LITERATUR}

\section{Perjalanan Dinas}

Dalam Anam $(2013,71)$ menjelaskan bahwa definisi Perjalanan dinas menurut Ignatus Wursanto adalah perjalanan yang dilakukan oleh seorang karyawan atau pegawai suatu lembaga atau perusahaan yang berkaitan dengan tugas pekerjaan kedinasan. Menurut Ignatius Wursanto bahwa ada beberapa dokumen perjalanan dinas yang harus disiapkan sebelum perjalanan dinas, yaitu: Surat Tugas dan Surat Perintah Perjalanan Dinas (SPPD).

Peraturan Menteri Dalam Negeri No.55 Tahun 2012 tentang Naskah Dinas, yaitu untuk melaksanakan pekerjaan sesuai dengan tugas dan fungsinya, dan melaksanakan suatu tugas bagi setiap Pejabat dan PNS termasuk pimpinannya. Untuk melakukan pencairan dana perjalanan dinas harus melampirkan berbagai persyaratannya seperti lampiran SPPD rincian biaya perjalanan dinas dan laporan perjalanan dinas (Kemendagri RI 2012).

Secara umum ada tiga macam alasan penerbitan SPPD, yaitu perintah 
langsung dari pimpinan, pelaksanaan program dan kegiatan SKPD (Surat Kegiatan Perjalanan Dinas) serta panggilan/undangan baik dari pemerintah provinsi atau daerah lain seperti diklat, rakor, lokalkarya, workshop, bimtek dan kegiatan sejenis. Khusus pengajuan SPPD untuk panggilan/undangan diharuskan melampirkan panggilan/undangan dimaksud. Yang perlu diteliti adalah sumber biaya dalam pelaksanaan panggilan/undangan apakah sumber biaya seluruhnya berasal dari daerah, atau sharing/konstribusi dari daerah.Ini dimaksudkan untuk menghindari adanya pembayaran ganda. Penulisan SPPD tidak diperkenankan adanya bekas hapusan/tindihan atau coretan (Bupati Bengkalis 2017).

\section{Motivasi Kerja}

Dalam Kadarsiman $(2012,34)$ menerangkan bahwa menurut Stokes motivasi kerja adalah sebagai pendorong bagi seseorang untuk melakukan pekerjaannya dengan baik, juga merupakan faktor yang membuat perbedaan antara sukses dan gagalnya dalam banyak hal dan merupakan tenaga emosional yang sangat penting untuk sesuatu pekerjaan baru. Sedangkan pendapat lainnya motivasi adalah dorongan yang dimiliki individu untuk melakukan tindakan tertentu berdasarkan kebutuhannya.

Dalam skala perusahaan motivasi individu dapat dipahami sebagai dorongan untuk mencapai tujuan perusahaan dan dirinya (Zainun 2004, 45). Motivasi biasanya timbul karena adanya kebutuhan yang tidak terpuaskan atau kebutuhan yang belum dapat terpenuhi. Kebutuhan ini akan menimbulkan tekanan dan tegangan sehingga akan menciptakan dorongan atau upaya untuk memenuhi kebutuhannya tersebut. Pada saat kebutuhan tersebut dapat terpuaskan maka individu akan mengalami penurunan tekanan (Asifudin 2004, 67).

Tujuan perintah motivasi kerja antara lain: mendorong gairah dan semangat kerja karyawan, meningkatkan moral dan kepuasan kerja karyawan, meningkatkan produktivitas kerja karyawan, mempertahankan loyalitas dan kestabilan karyawan perusahaan, meningkatkan kedisiplinan dan menurunkan tingkat absensi karyawan, mengefektifkan pengadaan karyawan, menciptakan suasana dan hubungan kerja yang baik, meningkatkan kreatifitas dan partisipasi karyawan, eningkatkan tingkat kesejahteraan karyawan, mempertinggi rasa tanggung jawab karyawan terhadap tugasnya, meningkatkan efisiensi penggunaan alat-alat dan bahan baku (Hasibuan 2008, 88).

Indikator untuk mengukur motivasi kerja yaitu: dorongan mencapai tujuan, semangat kerja, inisiatif dan kreatifitas dan rasa tanggung jawab (Yunarifah dan Lilik 2012, 32).

\section{Kerja Dalam Islam}

Menurut Asyraf, istilah "kerja" dalam Islam bukanlah semata-mata merujuk kepada mencari rezeki untuk menghidupi diri dan keluarga dengan menghabiskan waktu siang maupun malam, dari pagi hingga sore, terus menerus tak kenal lelah, tetapi kerja mencakup segala bentuk amalan atau pekerjaan yang mempunyai unsur kebaikan dan keberkahan bagi diri, keluarga dan masyarakat sekelilingnya serta negara (Khayatun 2008, 32).

Menurut Salmiyah (2008), dalam melakukan setiap pekerjaan, aspek etika merupakan hal mendasar yang harus selalu diperhatikan. Seperti bekerja dengan baik, didasari iman dan taqwa, sikap baik budi, jujur dan amanah, kuat, kesesuaian 
upah, tidak menipu, tidak merampas, tidak mengabaikan sesuatu, tidak semenamena (proporsional), ahli dan professional, serta tidak melakukan pekerjaan yang bertentangan dengan hukum Allah atau syariat Islam (Al-Qur'an dan Hadits).

Menjadi kewajiban umumnya PNS untuk melaksanakan tugas yang dibebankan kepadanya dan tidak meminta dan menuntut pemerintah untuk memberikan kepadanya apa yang tidak menjadi haknya. Jika mereka menuntut sesuatu yang tidak menjadi haknya maka pada dirinya sifat orang munafik yang Allah firmankan dalam Al-Qur'an Surah At-Taubah ayat 58 (Kemenag RI 2006):

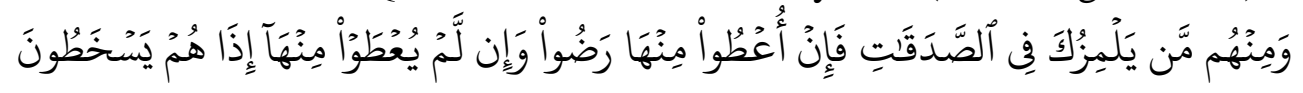

Artinya: "Dan di antara mereka ada orang yang mencelamu tentang (distribusi) harta zakat. Jika mereka diberi sebagian darinya, mereka bersenang hati namun jika mereka tidak diberi sebagian darinya, dengan serta merta mereka menjadi marah".

Etika kerja Islami memandang dedikasi untuk bekerja adalah suatu kebijakan. Sehingga untuk melakukan upaya yang cukup harus ada pad diri setip orang dalam pekerjaannya karena adanya pandangan bahwa pekerjan merupakan suatu bentuk kewajiban sehingga setiap orang harus mampu bekerja sama dan dapat mengatasi rintangan dan menghindari kesalahan secara bersama-sama. Etika kerja islami merupakan etika kerja yang bersumber pada syariah dengan mendidikasikan pekerjaan sebagai sebuah ibadah dan kebaikan dalam hidupnya, komitmen organisasional menggambarkan setiap orang harus memiliki sikap emosional melalui batas tertntu organisasi dan karyawan karna komitmen organisasional mampu menjadi faktor yang memungkinkan karyawan tetap di organisasinya (Rachmawati dan Ketut 2016, 270).

\section{Motivasi Dalam Islam}

Motivasi adalah kekuatan-kekuatan dari dalam diri individu yang menggerakkan individu untuk berbuat. Jadi suatu kekuatan atau keinginan yang datang dari dalam hati nurani manusia untuk melakukan suatu perbuatan tertentu (Anwar 2011). Motivasi kerja dalam Islam itu adalah untuk mencari nafkah yang merupakan bagian dari ibadah. Motivasi kerja dalam Islam bukanlah untuk mengejar hidup hedonis, bukan juga untuk status, apa lagi untuk mengejar kekayaan dengan segala cara. Dengan demikian, motivasi kerja dalam Islam, bukan hanya memenuhi nafkah semata tetapi sebagai kewajiban beribadah kepada Allah setelah ibadah fardlu lainnya. Bekerja untuk mencari nafkah adalah hal yang istimewa dalam pandangan Islam.

Allah telah berjanji kepada orang yang beriman dan melakukan pekerjaan yang baik bahwa bagi mereka ampunan Allah dan ganjaran yang besar. Firman Allah SWT. dalam Surah An-Nisa ayat 66-68 (Kemenag RI 2006):

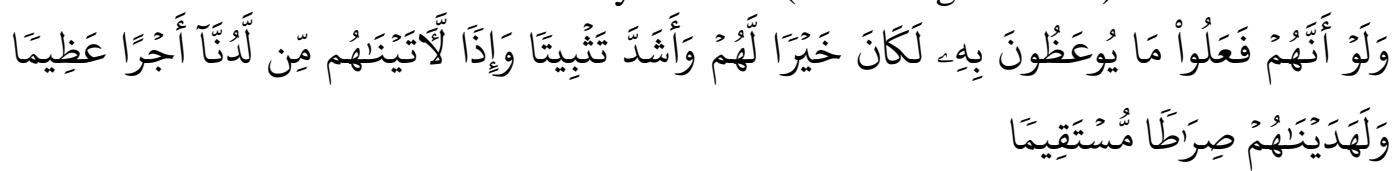

Artinya: "Dan Sesungguhnya kalau mereka melaksanakan pelajaran yang diberikan kepada mereka, tentulah hal yang demikian itu lebih baik bagi mereka dan lebih menguatkan (iman mereka). Dan kalau demikian, pasti kami berikan kepada mereka pahala yang besar dari sisi kami. Dan pasti kami tunjuki mereka kepada jalan yang lurus". 
Al-Qur'an menyatakan: "Dan di langit terdapat (sebab-sebab) rezekimu dan terdapat (pula) apa yang dijanjikan kepadamu". (QS. Adz-Dzariyat) "Dan tidak ada suatu makhluk (daabbah) pun di bumi, melainkan Allah lah yang menjamin rezekinya". (QS. Huud) "Dan berapa banyak binatang yang tidak dapat mencari rezekinya sendiri, Allahlah yang memberi rezeki kepadanya dan juga kepadamu". (QS. Al-Ankabut).

Dalam melaksanakan perjalanan dinas ASN hendaknya selalui menghargai waktu dalam menyelesaikan pekerjaannya dan sebagai umat manusia kita harus mencermati nilai waktu yaitu dengan menggunakan waktu sebaik-baiknya dalam bekerja. Seperti firman Allah dalam Al-Qur'an Surah Al-'Asr ayat 1-3 (Kemenag RI 2006):

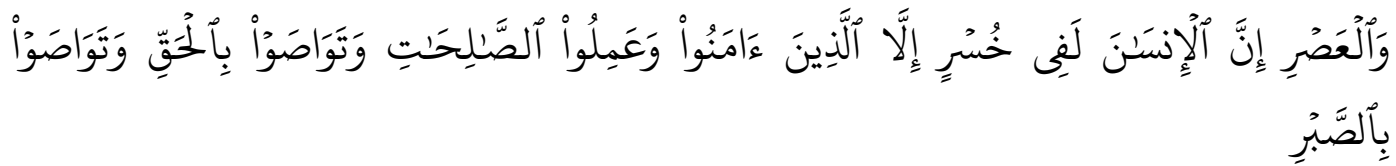

Artinya: Demi Masa, sesungghnya manusia itu benar-benar dalam kerugian, kecuali orang-orang yang beriman dan mengerjakan amal saleh dan nasehat menasehati supaya mentaati kebenaran dan nasehat menasehati supaya menetapi kesabaran.

Dari penjabaran teori di atas dapat dibuat hipotesis yaitu terdapat pengaruh antara perintah perjalanan dinas terhadap peningkatan motivasi kerja aparatur sipil negara di Sekretariat DPRD Kabupaten Bengkalis.

\section{METODE PENELITIAN}

Penelitian ini dilakukan pada kantor Sekretariat DPRD Kabupaten Bengkalis pada tahun 2019. Populasi dalam penelitian ini sebanyak 68 orang, sedangkan dalam pengambilan sample penulis menggunakan Non probability Sampling dengan kaedah Quota Sampling sehingga jumlah sample yang diambil adalah sebanyak 57 orang. Teknik pengumpulan data yang digunakan yaitu: kuesioner, observasi, wawancara dan studi pustaka. Penelitian ini menggunakan metode deskriptif kuantitatif. Sedangkan teknik analisa yang digunakan adalah analisis regresi linier sederhana.

\section{HASIL DAN PEMBAHASAN PENELITIAN}

\section{Perintah Perjalanan Dinas di Sekretariat DPRD Kabupaten Bengkalis}

Agar perjalanan dinas pimpinan berjalan lancar sesuai dengan yang diharapkan, administrasi kantor/sekretaris harus selalu berkoordinasi dengan pimpinan ketika mempersiapkan semua hal yang diperlukan dalam perjalanan dinas. Apabila administrasi kantor/sekretaris kurang berkoordinasi dengan pimpinan, administrasi kantor/sekretaris tentu akan menemui kesulitan untuk mempersiapkan perjalanan dinas pimpinan. Persiapan perjalanan dinas pimpinan meliputi Persiapan Rencana Perjalanan Dinas.

Dalam merencanakan perjalanan dinas, administrasi kantor/sekretaris harus segera mengumpulkan informasi perjalanan (travelling information) secara lengkap mengenai peraturan perjalanan dinas diperusahaan tersebut. Informasi yang perlu dikumpulkan tersebut, antara lain: Siapa yang bertanggung jawab dalam perjalanan dinas, dan tujuan utama perjalanan dinas pimpinan. 
Sebagaimana yang terdapat dalam Perbub No. 82 tahun 2017 pada bab IV bahwa ada beberapa golongan perjalanan dinas diantaranya: Perjalanan dinas untuk Bupati dan Wakil Bupati; Perjalanan dinas untuk tingkat A untuk Pimpinan DPRD dan Anggota DPRD; Perjalanan dinas tingkat B untuk pejabat Pimpinan Tinggi Pratama; Perjalanan dinas tingkat $\mathrm{C}$ untuk pejabat Administrator; Perjalanan dinas tingkat D untuk Pejabat Pengawas Auditor; Perjalanan dinas tingkat E untuk pegawai ASN Golongan IV dan III; Perjalanan dinas tingkat F untuk pegawai ASN golongan II dan I; dan Perjalanan dinas untuk Pegawai Non ASN.

Berdasarkan hasil wawancara yang diberikan kepada masing-masing bidang, penulis mendapatkan bahwa mekanisame perjalanan dinas oleh ASN dan non PNS dilingkungan Sekretariat DPRD kabupaten Bengkalis berjalan sesuai dengan Perbub dalam pasal 26 diantaranya: pegawai ASN/pegawai Non PNS dan Anggota DPRD yang akan melasanakan perjalanan dinas harus terlebih dahulu mendapat persetujuan dan perintah atasan/pimpinan; Perjalanan dinas dilakukan berdasarkan SPPD yang diterbitkan oleh pejabat yang berwenang; Pejabat yang berwenang hanya bisa menerbitkan SPPD untuk perjalanan dinas yang biayanya dibebankan pada anggaran yang tersedia dalam DPA-PD berkennaan, kecuali hal teknis yang harus melibatkan PD lain/instansi yang terkait (Bupati Bengkalis 2017).

Hal-hal lain mengenai penenenutan siapa yang harus mendapatkan giliran untuk melakukan perjalanan dinas di lingkungan sekretariat DPRD tergantung kepada siapa yang ditunjuk oleh ketua dewan atau anggota dewan yang mereka anggap perlu dan berkompeten dalam pelaksanaan pekerjaan yang mereka lakukan.

Perintah perjalanan dinas kepada ASN di lingkup Sekretariat DPRD Kabupaten Bengkalis terdiri dari beberapa kegiatan, ada yang bersifat perjalanan dinas pendampingan, konsultasi, keprotokoleran dan peliputan yang kesemuanya itu mempunyai nomenklatur dan rekening anggaran yang berbeda. Setiap perjalanan dinas dibayarkan sesuai dengan pangkat, jabatan dan golongan ASN dan tidak melebihi pagu anggaran serta sesuai dengan Peraturan Bupati yang telah ditetapkan.

Karena banyaknya ASN yang berada di lingkup Sekretariat DPRD Kabupaten Bengkalis serta beragamnya perjalanan dinas yang dilakukan, maka penulis melakukan analisa terhadap ASN tersebut. Setiap ASN yang menjadi sampel penulis berikan kuisioner untuk diisi dan ada juga beberapa sampel yang dilaksanakan wawancara. Dan berdasarkan sesi wawancara tersebut, penulis hasil bahwa: (1) Perjalanan dinas yang dilaksanakan di Sekretariat DPRD Kabupaten Bengkalis sudah mengacu pada Peraturan Bupati (Perbup). (2) Di dalam proses Perintah mandat untuk melaksanakan perjalanan dinas, diberlakukan penentuan khusus yang mana orang yang ditunjuk untuk melaksanakannya harus sesuai dengan tupoksi dan kemampuannya. (3) Syarat untuk melaksanakan perjalanan dinas adalah ASN/Non ASN yang bersifat teknis. (4) Ada beberapa prosedur yang wajib dilaksanakan oleh mereka yang melaksanakan perjalanan dinas yaitu nota dinas, SPT, SPPD, Visum (Bukti) dan Laporan Perjalanan Dinas. 


\section{Hasil Uji Validitas Data}

Tabel 1 Hasil Uji Validitas Kuesioner Variabel Perintah Perjalanan Dinas (X)

\begin{tabular}{cccc}
\hline Pertanyaan & $\mathbf{r}_{\text {hitung }}$ & $\mathbf{r}_{\text {tabel }}$ & Keterangan \\
\hline 1 & 0,375 & 0,2609 & Valid \\
2 & 0,400 & 0,2609 & Valid \\
3 & 0,457 & 0,2609 & Valid \\
4 & 0,532 & 0,2609 & Valid \\
5 & 0,394 & 0,2609 & Valid \\
6 & 0,455 & 0,2609 & Valid \\
7 & 0,457 & 0,2609 & Valid \\
8 & 0,565 & 0,2609 & Valid \\
9 & 0,510 & 0,2609 & Valid \\
10 & 0,487 & 0,2609 & Valid \\
\hline
\end{tabular}

Sumber: olahan peneliti

Tabel 2 Hasil Uji Validitas Kuesioner Variabel Motivasi Kerja (Y)

\begin{tabular}{cccc}
\hline Pertanyaan & $\mathbf{r}_{\text {hitung }}$ & $\mathbf{r}_{\text {tabel }}$ & Keterangan \\
\hline 1 & 0,453 & 0,2609 & Valid \\
2 & 0,445 & 0,2609 & Valid \\
3 & 0,469 & 0,2609 & Valid \\
4 & 0,472 & 0,2609 & Valid \\
5 & 0,501 & 0,2609 & Valid \\
6 & 0,584 & 0,2609 & Valid \\
7 & 0,648 & 0,2609 & Valid \\
8 & 0,529 & 0,2609 & Valid \\
9 & 0,605 & 0,2609 & Valid \\
10 & 0,555 & 0,2609 & Valid \\
\hline
\end{tabular}

Sumber: olahan peneliti

Berdasarkan hasil tabel 1 dan tabel 2 di atas, dapat dikatakan bahwa dari 20 pernyataan yang diajukan dalam bentuk kuesioner oleh peneliti kepada 57 responden, semua pernyataan tersebut dinyatakan valid. Karena, berdasarkan hasil analisa statistik tersebut bahwa nilai $r_{\text {hitung }}$ lebih besar dari $r_{\text {tabel }}$, dimana nilai $r_{\text {tabel }}$ didapat dari distribusi tabel $r$ dengan posisi $n=57,(d f=n-2=57-2=55)$ dan taraf kesalahan 5\% sehingga nilai $r_{\text {tabel }}=0,2609$.

\section{Hasil Uji Reliabilitas}

Tabel 3 Hasil Uji Reliabilitas

\begin{tabular}{ccc}
\hline Cronbach's Alpha & $\begin{array}{c}\text { Cronbach's Alpha Based } \\
\text { on Standardized Items }\end{array}$ & N of Items \\
\hline $\mathbf{8 2 2}$ &, 880 & 22 \\
\hline Sumber: Outpus SPSS & &
\end{tabular}


Berdasarkan tabel 3 di atas, dapat dikatakan bahwa 20 pernyataan yang diajukan peneliti adalah reliabel karena nilai Cronbach's Alphanya (0.822) lebih besar dari nilai acuan standar untuk uji reliabilitas data yaitu $(0,6)$.

\section{Hasil Uji Normalitas}

Dalam pembahasan ini akan digunakan uji One Sample KolmogorovSmirnov dengan menggunakan taraf signifikansi 0,05. Data dinyatakan berdistribusi normal jika signifikansi lebih besar dari 5\% atau 0,05.

Tabel 4 Hasil Uji Normalitas

\section{Kolmogorov-Smirnov ${ }^{a} \quad$ Shapiro-Wilk}

\begin{tabular}{ccccccc} 
& Statistic & Df & Sig. & Statistic & Df & Sig. \\
\hline JLH X &, 104 & 57 & $\mathbf{, 1 9 0}$ &, 986 & 57 & $\mathbf{, 7 3 9}$ \\
\hline JLH Y &, 113 & 57 & $\mathbf{, 0 6 8}$ &, 985 & 57 & $\mathbf{, 7 2 0}$ \\
\hline Sumber: Outpus SPSS & & &
\end{tabular}

Berdasarkan tabel 4 di atas, dapat dikatakan bahwa variabel $\mathrm{X}$ dan $\mathrm{Y}$ berdistribusi normal karena nilai signifikan masing-masing variabel lebih besar dari 0,05 yaitu $X=0.190$ dan $Y=0,068$.

\section{Hasil Uji Homogenitas}

Uji homogenitas digunakan untuk mengetahui apakah beberapa varian populasi adalah sama atau tidak. Sebagai kriteria pengujian, jika nilai signifikansi lebih dari 0,05 maka dapat dikatakan bahwa varian dari dua atau lebih kelompok data adalah sama.

Tabel 5 Hasil Uji Normalitas

\begin{tabular}{cccc}
\hline Levene Statistic & df1 & df2 & Sig. \\
\hline 1,673 & 1 & 55 & $\mathbf{1 1 4}$ \\
\hline Sumber: Outpus SPSS & & &
\end{tabular}

Berdasarkan tabel 5, dapat dikatakan bahwa varian populasi variabel $\mathrm{X}$ dan Y sama karena nilai signifikan lebih besar dari 0,05 yaitu 0,114.

\section{Hasil Uji Regresi Linear Sederhana}

Analisis Regresi Linier Sederhana adalah hubungan secara linier antara satu variabel independen (X) dan variabel dependen (Y). Analisi ini untuk mengetahui arah hubungan antara variabel.

Tabel 6 Koefisien Regresi Sederhana

\begin{tabular}{lccccc}
\hline Model & \multicolumn{2}{c}{$\begin{array}{c}\text { Unstandardized } \\
\text { Coefficients }\end{array}$} & $\begin{array}{c}\text { Standardized } \\
\text { Coefficients }\end{array}$ & t & Sig. \\
& $\boldsymbol{B}$ & $\begin{array}{c}\text { Std. } \\
\text { Error }\end{array}$ & Beta & & \\
\hline $1 \quad$ (Constant) & 16,887 & 4,304 & & 3,923 &, 000 \\
PPD &, 606 &, 124 &, 551 & 4,897 &, 000 \\
\hline $\begin{array}{l}\text { a. Dependent Variable: MOTIVASI KERJA } \\
\text { Sumber: Outpus SPSS }\end{array}$ & & & & \\
\end{tabular}


Hasil penghitungan koefisien regresi sederhana diatas memperlihatkan nilai koefisien konstanta adalah sebesar 16,887 dan koefisien variabel bebas (X) adalah sebesar 0,606. Sehingga diperoleh persamaan regresi $Y=16,887+0,606 \mathrm{X}$. Berarti bahwa setiap penambahan 1 nilai perintah perjalanan dinas, maka nilai motivasi kerja aparatur sipil negara meningkat sebesar 0,606.

\section{Hasil Uji Hipotesis}

Untuk pengujian hipotesis dapat dilakukan dengan Uji t. Dari tabel 6 tersebut didapat nilai $t_{\text {hitung }}$ adalah $4,897, t_{\text {tabel }}$ dicari dengan $\alpha=5 \%: 2=2,5 \%=0,025$ dengan derajat kebebasan (df) $\mathrm{n}-2=57-2=55 . \mathrm{T}_{\text {tabel }}$ diperoleh sebesar 2,004 (lihat pada distribusi $\mathrm{t}_{\text {tabel }}$ ). Parameter hipotesis dalam uji $\mathrm{t}$ adalah: $\mathrm{H}_{1}$ diterima jika $t_{\text {hitung }}>\mathrm{t}_{\text {tabel }}, \mathrm{H}_{1}$ ditolak jika $\mathrm{t}_{\text {hitung }}<\mathrm{t}_{\text {tabel }}$. Untuk itu dapat dibandingkan bahwa nilai $t_{\text {hitung }}(4,897)>t_{\text {tabel }}(2,004)$ oleh karena itu dapat dinyatakan bahwa $\mathrm{H}_{1}$ diterima dan $\mathrm{H}_{0}$ ditolak, sehingga perintah perjalanan dinas berpengaruh terhadap peningkatan motivasi kerja aparatur sipil negara di Sekretariat DPRD Kabupaten Bengkalis.

\section{Hasil Uji Koefisien Determinan}

Tabel 7 Uji Koefisien Determinan

\begin{tabular}{ccccc}
\hline Model & $\boldsymbol{R}$ & $\boldsymbol{R}$ Square & $\begin{array}{c}\text { Adjusted } \boldsymbol{R} \\
\text { Square }\end{array}$ & $\begin{array}{c}\text { Std. Error of } \\
\text { the Estimate }\end{array}$ \\
\hline 1 &, $551^{\mathrm{a}}$ &, 304 &, 291 & 3,964 \\
\hline a. Predictors: (Constant), $\mathrm{PPD}$ & & &
\end{tabular}

Sumber: Outpus SPSS

Berdasarkan tabel $7 \mathrm{di}$ atas dapat dilihat bahwa nilai $\mathrm{R}$ Square sebesar $0,304=30,4 \%$. Berarti besar pengaruh perintah perjalanan dinas terhadap peningkatan motivasi kerja aparatur sipil negara di Sekretariat DPRD Kabupaten Bengkalis adalah sebesar 30,4\%. Sementara sisanya sebesar 69,6\% merupakan pengaruh variabel lain yang tidak dibahas dalam penelitian ini.

\section{Perintah Perjalanan Dinas Pada Sekretariat DPRD Kabupaten Bengkalis di Tinjauan Dari Perspektif Islam}

Berdasarkan Al-Qur'an surah An-Nisa' 59 dapat ditafsirkan bahwa perintah perjalanan dinas merupakan salah satu cara taat kepada pemimpin untuk melaksanakan tugas Negara yang berdampak kepada kepentigan daerah. Dari aspek akad atau transaksi, dapat dipilah menjadi dua opsi, yaitu transaksi sewa manfaat (ijarah) atau transaksi imbalan tertentu atas pencapaian hasil (ju'alah). Opsi pertama adalah transaksi yang disepakati adalah ijarah.

Berdasarkan transaksi ini, pegawai tersebut berhak mendapatkan upah atas jasa pekerjaan atau menyelesaikan pekerjaan tertentu berbasis harian. Oleh karena itu, jika dipersingkat, upah sah yang diambil adalah sejumlah hari yang riil ditunaikan. Sedangkan, sisanya dikembalikan kepada instansi atau kantor terkait yang memerintahkannya kecuali jika instansi tersebut merelakannya.

Opsi kedua adalah transaksi yang disepakati adalah imbalan tertentu atas pencapaian hasil (ju'alah). Berdasarkan Fatwa DSN-MUI No. 
62/DSNMUI/XII/2007 tentang Akad ju'alah. Ju'alah adalah janji atau komitmen (iltizam) untuk memberikan imbalan (reward/'iwadh/ju'l) tertentu atas pencapaian hasil (natijah) yang ditentukan dari suatu pekerjaan.

Dengan demikian, berdasarkan akad ju'alah, reward yang menjadi hak peserta/pegawai bukan berbasis harian, melainkan hasil. Jika waktu yang ditentukan tiga hari, tetapi output-nya sudah bisa selesai dalam dua hari, biaya tersebut sudah halal diterima dan dimanfaatkan pegawai. Jika ini yang diberlakukan, reward yang didapatkan pegawai atas progres yang dihasilkan walaupun waktunya di persingkat itu diperkenankan atau halal.

\section{KESIMPULAN}

Perjalanan dinas Aparatur Sipil Negara di Sekretariat DPRD Kabupaten Bengkalis sudah sesuai dengan Peraturan Bupati No. 82 tahun 2017. Perintah perjalanan dinas mempunyai pengaruh yang signifikan terhadap motivasi kerja Aparatur Sipil Negara di lingkungan Sekretariat DPRD Kabupaten Bengkalis, nilai pengaruhnya yaitu sebesar 30,4\% sedangkan sisanya 69,6\% dipengaruhi oleh variabel lain. Kemudian dalam Islam, perjalanan dinas boleh-boleh saja dilakukan asal tidak melanggar aturan yang ada, walaupun tidak ada dalil atau nash yang menyebut secara khusus mengenai hal tersebut.

\section{DAFTAR PUSTAKA}

Anam, Zidni Maghfirotul. 2013. Pengaruh Gaya Kepemimpinan Manajer Dan Motivasi Kerja Karyawan Terhadap Kinerja Karyawan Pada Bengkel JASATEC Cabang Gombong. Tugas Akhir Fakultas Ekonomi Universitas Negeri Yogyakarta.

Anwar, Zainul. 2011. Motivasi Dan Ice Breaking. Diakses dari http://zainulanawr.staff.umm.ac.id/2011/03/05/motivasi-ice-breaking/, tanggal 26 Oktober 2018.

Arikunto. 2010. Prosedur Penelitian: Suatu Pendekatan Praktek. Jakarta: Rineka Cipta.

Asifudin, Ahmad Janan. 2004. Etos Kerja Islami. Surakarta: Muhammadiyah Universitas Press.

Batan. Diakses dari: http//www.batan.go.id, tanggal 10 Desember 2018.

Bupati Bengkalis. 2017. Peraturan Bupati Bengkalis Nomor 78 Tahun 2017 Tentang Naskah Dinas.

Dewan Syari'ah Nasional. 2007. Fatwa Dewan Syari'ah Nasional Nomor 62/DSN-MUI/XII/2007 Tentang Akad Ju'alah.

Erlindawati. 2016. "Motivasi Masyarakat Dalam Membayar Zakat Untuk Meningkatkan Kesejahteraan". IQTISHADUNA: Jurnal Ilmiah Ekonomi Kita 5 (2), 187-205.

Eryana. 2017. "Pengaruh Budaya Organisasi Dan Komitmen Organisasi Terhadap Motivasi Kerja Karyawan Rumah Sakit Lancang Kuning Pekanbaru”. IQTISHADUNA: Jurnal Ilmiah Ekonomi Kita 6 (1), 66-81. 
Fakhruddin. 2016. Ulil Amri yang Wajib Ditaati. Diakses dari: https://www.kiblat.net/2016/04/12/ulil-amri-yang-wajib-ditaati, tanggal 20 April 2019.

Gouzaly, Saydam. 2000, Manajemen Sumber Daya Manusia. Jakarta: Gunung Agung.

Hasibuan, Malayu S.P. 2008. Organisasi Dan Motivasi. Jakarta: PT. Bumi Aksara.

Iskandar. 2009. Metodologi Penelitian Pendidikan dan Sosial. Jakarta: GP Press.

Kadarsiman. 2012. Manajemen Pengembangan Sumber Daya Manusia. Jakarta: PT Rajagrafindo.

Kementerian Agama RI. 2006. Al-Quran. Jakarta: PT. Karya Toha Putra.

Kementrian Dalam Negeri RI. 2012. Peraturan Dalam Negeri Nomor 55 Tahun 2012 tentang Naskah Dinas.

Khayatun. 2008. Etos Kerja dalam Islam. Jakarta: DKSI-IPB.

Mangkunegara, Anwar Prabu. 2004. Manajemen Sumber Daya Manusia Perusahaan. Bandung: PT Remaja Rosdakarya.

Mangkunegara, Anwar Prabu. 2012. Evaluasi Kinerja Sumber Daya Manusia. Bandung: PT Refika Aditama.

Mardalis. 2004. Metode Penelitian Suatu Pendekatan Proposal. Jakarta: Bumi Aksara.

Nuryana, Mu'man. 2005. Comperate Social Responsibility. Makalah Pada Balai Besar Pendidikan dan Pelatihan Kesejahteraan Sosial (BBPPKS) Bandung.

Pawewang, Anggi Daeng. 2015. "Motivasi Kerja Aparatur Dalam Penyelenggaraan Pemerintahan Di Kecamatan Poigar Kabupaten Bolaang Mongonsow". Jurnal Eksekutif 1 (4).

Pramandhika, Ananto. 2011. Motivasi Kerja Dalam Islam (Studi Kasus pada Guru TPQ di Kecamatan Semarang Selatan). Tesis Universitas Diponegoro.

Pratama, Muhammad Rahmaditya. 2015. "Pengaruh Insentif Terhadap Motivasi Kerja (Studi Pada Karyawan Atria Hotel And Conference Malang)”. Jurnal Administrasi Bisnis 25 (2), 1-6.

Rachmawati, Tiara dan Ketut Sudama. 2016. "Pengaruh Etika Kerja Islam Pada Komitmen Organisasional Dengan Motivasi Interinsik Sebagai Variabel Pemediasi”. Manajemen Analisis Journal 5 (3), 269-280.

Salmiyah, Abi Ummu. 2008. Etika Kerja Dalam Islam. Diakses dari https://tarbiyah2008.wordpress.com/2008/02/25/etika-kerja-dalam-islam/, tanggal 26 November 2018.

Siagian, P. Sondang. 1989. Teori Motivasi dan Aplikasinya. Jakarta: PT. Rineka Cipta.

Sinungan, Muchdarsyah. 2003. Produktivitas Apa dan Bagaimana. Jakarta: Bumi Aksara.

Sugiyono. 2005. Metodologi Penelitian Administrasi. Yogjakarta: CV Alfabeta.

Sugiyono. 2010. Statistik Untuk Penelitian. Jakarta: Rineka Cipta.

Sugiyono. 2014. Metode Penelitian Pendidikan Pendekatan Kuantitatif, Kualitatif, dan R\&D. Bandung: Alfabeta.

Sukirwan, Arwan. 2018. "Insentif Terhadap Produktivitas Kerja Pustakawan Pada Perpustakaan Universitas Negeri Jakarta Dan Tinjauannya Menurut Islam”. Jurnal Imam Bonjol 2 (1), 36-55. 
Syamsudin, Zainal Abidin. 2008. Mencari Kunci Rizki Yang Hilang: Jakarta. Pustaka Imam Abu Hanifah.

Tjandra, Happy Sugiarto. 2004. MOTIF-8 Koleksi Motivasi Untuk Karir dan Kehidupan Yang Lebih Baik. Jakarta: PT. Gramedia.

Yunarifah, Usri Nani dan Lilik Kustiani. 2012. "Pengaruh Motivasi Kerja Terhadap Kinerja Karyawan PT. Kebon Agung Malang". Jurnal Manajemen Bisnis 8 (2), 145-164.

Winardi, Jhon. 2002. Motivasi dan Pemotovasian dalam Manajemen. Jakarta: Rajawali Press.

Zainun, Buchari. 2004. Manajemen dan Motivasi. Jakarta: Balai Aksara. 